\title{
Advances in Asset Management Techniques: An Overview of Corrosion Mechanisms and Mitigation Strategies for Oil and Gas Pipelines
}

\author{
Chinedu I. Ossai \\ Production Planning Department, Overall Forge Pty Ltd, 70 R W Henry Drive, Ettamogah near Albury, P.O. Box 5275, \\ Albury, NSW 2640, Australia \\ Correspondence should be addressed to Chinedu I. Ossai, ossaic@gmail.com
}

Received 2 August 2012; Accepted 28 August 2012

Academic Editors: G. Bereket, C. Gu, and R. Salghi

Copyright ( $) 2012$ Chinedu I. Ossai. This is an open access article distributed under the Creative Commons Attribution License, which permits unrestricted use, distribution, and reproduction in any medium, provided the original work is properly cited.

Effective management of assets in the oil and gas industry is vital in ensuring equipment availability, increased output, reduced maintenance cost, and minimal nonproductive time (NPT). Due to the high cost of assets used in oil and gas production, there is a need to enhance performance through good assets management techniques. This involves the minimization of NPT which accounts for about $20-30 \%$ of operation time needed from exploration to production. Corrosion contributes to about $25 \%$ of failures experienced in oil and gas production industry, while more than $50 \%$ of this failure is associated with sweet and sour corrosions in pipelines. This major risk in oil and gas production requires the understanding of the failure mechanism and procedures for assessment and control. For reduced pipeline failure and enhanced life cycle, corrosion experts should understand the mechanisms of corrosion, the risk assessment criteria, and mitigation strategies. This paper explores existing research in pipeline corrosion, in order to show the mechanisms, the risk assessment methodologies, and the framework for mitigation. The paper shows that corrosion in pipelines is combated at all stages of oil and gas production by incorporating field data information from previous fields into the new field's development process.

\section{Introduction}

The oil and gas industry is an asset intensive business with capital assets ranging from drilling rigs, offshore platforms and wells in the upstream segment, to pipeline, liquefied natural gas (LNG) terminals, and refineries in the midstream and downstream segments. These assets are complex and require enormous capital to acquire. An analysis of the five major oil and gas companies (BP, Shell, ConocoPhillips, Exxonmobil, and Total) shows that plant, property, and equipment on average accounts for $51 \%$ of the total assets with a value of over $\$ 100$ billion [1]. Considering the huge investment in assets, oil and gas companies are always under immense pressure to properly manage them. To achieve this involves the use of different optimization strategies that is aimed at cost reduction and improved assets reliability [2].

Due to the growth in the demand of oil and gas around the world, companies are developing new techniques to reach new reservoirs in the offshore and onshore arena [3]. This is putting pressure on most of the facilities with the attendant cost of maintenance soaring [1]. The continuous utilization and the ageing of facilities have resulted in record failures in the oil and gas plants. Research shows that between 1980 and 2006, 50\% of European, major hazards of loss containment events arising from technical plants failures were primarily due to ageing plants mechanism caused by corrosion, erosion, and fatigue $[4,5]$.

A study shows that corrosion cost in US rose above $1 \$$ trillion in 2012 accounting for about 6.2\% of GDP hence, the largest single expense in the economy [6]. In the oil and gas company, corrosion accounts for over $25 \%$ of assets failure [7] and is found to be prevalent in every stage of the production cycle. Oxygen which plays a dominant role in corrosion is normally present in producing formation water. During drilling operation, drilling mud can corrode the well casing, drilling equipment, pipeline, and the environment. 
Water and $\mathrm{CO}_{2}$ produced or injected for secondary recovery can cause severe corrosion of completion strings, while the acids used to reduce formation damage around the well or to remove scale can attack metals [8]. The formation water and injected water used for the oil recovery are a potential source of pipeline corrosion during transportation of the oil from the wells to the loading terminals. Mechanical static equipment like valves, tanks, vessels, separators, and so forth are susceptible to a different kind of corrosion however, pipelines are more prone to corrosion due to the presence of $\mathrm{CO}_{2}, \mathrm{H}_{2} \mathrm{~S}, \mathrm{H}_{2} \mathrm{O}$, bacteria, sand, and so forth in the fluid.

Owing to the increasing cost of pipeline corrosion management in the oil and gas industries [1], operators are becoming more concerned about corrosion management planning at all phases of production. Corrosion information from existing field data is being incorporated into design information for new oil and gas field $[9,10]$ in a bid to develop appropriate corrosion management methodologies that will enhance the design life of the pipelines and optimize production. To reduce the risk of microbiologically influenced Corrosion (MIC) and other associated corrosions like stress corrosion cracking (SCC), hydrostatic testing of carbon steel pipes should be carried out in such a manner that enhances the future pipeline service conditions by using the right source of water, ensuring proper degree of filtration, ensuring limited exposure period to temperature and eliminating air packets [11]. Though bacteria in the biofilm are responsible for pitting of a pipeline in a MIC however, the impact of the flow velocity of the constituent fluid influences the mass transfer rate thereby affecting the biofilm formation, hence, inhibiting the activities of sulphate reducing bacteria, (SRB) present in the fluid [12]. This flow attribute has significant impact in MIC in oil and gas pipeline.

Considering the fact that the $\mathrm{CO}_{2}$ and $\mathrm{H}_{2} \mathrm{~S}$ induced corrosion rate can reach up to $6 \mathrm{~mm} / \mathrm{yr}$ and $300 \mathrm{~mm} / \mathrm{yr}$, respectively, [13] in oil and gas pipelines, sophistication in inspection and monitoring techniques is therefore necessary for quick mitigation. The increased trend in in-line inspection and online data acquisition has helped in quicker data acquisition, analysis, and decision making regarding corrosion in pipelines. The enhanced research knowledge of the behaviour of these corrodents $\left(\mathrm{CO}_{2}\right.$ and $\mathrm{H}_{2} \mathrm{~S}$, acetic acid, etc.) at different operating conditions [14-17] has given rise to numerous mechanistic, statistical, and empirical models [18-23] which have contributed immensely in the inspection and monitoring, selection of inhibitors, and materials selection for pipelines design.

Since corrosion is a dominant factor contributing to failures and leaks in pipelines [24], to aid industry experts in managing the integrity of pipelines therefore involves a layout of the developments in the management strategies. This involves the recognition of the conditions contributing to the corrosion incident and identifying effective measures that can be taken to mitigate against them. To facilitate best practices in pipeline integrity management therefore, requires a framework that utilizes good policies and procedures in inspection, data collection, and interpretation for corrosion control.

\section{Overview of Corrosion}

Corrosion is a naturally occurring phenomena commonly defined as the deterioration of a substance (usually metal) or its properties because of a reaction with its environment [25]. Corrosion of materials is inevitable due to the fundamental need of lowering of Gibbs energy [26]. Every material is trying to achieve a lower energy state hence the ability to corrode in order to get to a low energy oxide state. Though this is the case with all materials, the major focus of experts however, is to achieve an equilibrium position between the materials and the environment thereby controlling corrosion.

Modern corrosion science has its roots in electrochemistry and metallurgy. Whereas electrochemistry contributes to the understanding of materials via corrosion, metallurgy provides information about the behaviour of the material and their alloys hence provide a medium for combating the degradation on them. The type of corrosion mechanism and its rate of attack depend on the nature of the environment (air, soil, water, etc.) in which the corrosion takes place. Whereas some environmental condition can help to mitigate the rate of corrosion, others help to increase it hence, industrial wastes and products can either be corrosion inhibitor or catalyst. For instance, $\mathrm{CO}_{2}, \mathrm{H}_{2} \mathrm{~S}$, temperature, mass flow rate, $\mathrm{pH}$, formation water, and so forth contribute in no small measure to the rate of corrosion in oil and gas pipeline $[14,16,17,27]$. The existence of anodic cathodic sites on the surface of a piece of metal implies that the difference in electrical potential is found on the surface. This potential difference has the tendency of initiating corrosion. If an oil and gas pipeline passes through a zone of clay soil (where the oxygen concentration is low) to gravel (where the oxygen concentration is high), the part of the pipeline in contact with the clay becomes anodic and suffers damage. Though this problem is extensively addressed with the cathodic protection [26], concentration cell may also be formed where there are differences in metal ion concentration.

Although most metals are crystalline in form, they generally are not continuous single crystal but rather are collections of small grains of domains of localized order in which microcrystal forms as the liquid cools and solidifies. In the final states, the crystals have different orientation with respect to one another. The edge of the domain form grain boundaries which are an example of planar defects in metal. These defects are usually sites of chemical reactivity. The boundaries are also weaknesses, the places where stress corrosion cracking begins. The metallic surface exposed to an aqueous electrolyte usually possesses site for oxidation (anodic reaction) that produces electrons in the metal and reduction (cathodic reaction) that consumes the electrons produced by the anodic reaction $[25,26]$. These sites make up a corrosion cell. The anodic reaction (Figure 1) involves the dissociation of metal to form either soluble ionic product or an insoluble compound of metal usually an oxide. For cathodic reaction (Figure 2), oxygen gas generated could be reduced or water is reduced to produce hydrogen gas. The simultaneous reaction of the anodic and cathodic reactions produces the electrochemical cell. 


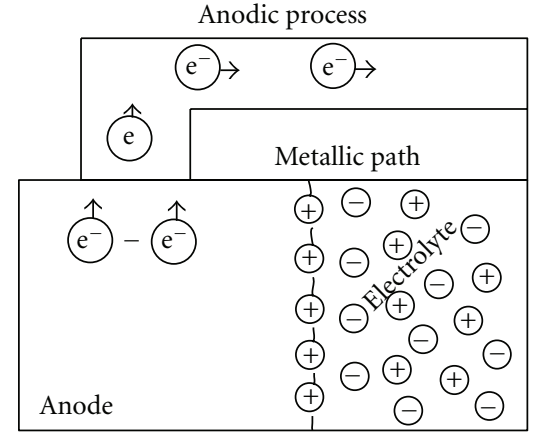

FIgURe 1: Anodic process.

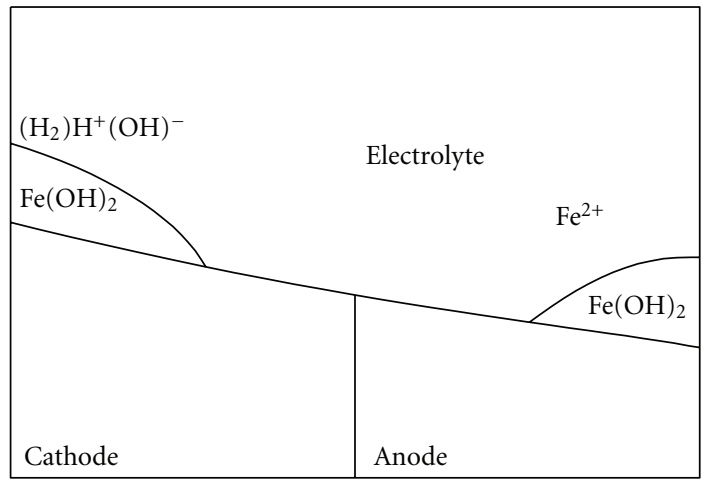

FIgure 2: Cathodic process.

In completely oxygen-free water, the cathodic reaction that takes place is the reaction of hydrogen ion to form hydrogen gas as shown in (1):

$$
2 \mathrm{H}^{+}+2 \mathrm{e}^{-} \longrightarrow \mathrm{H}_{2}(\mathrm{~g})
$$

When significant amounts of oxygen are present in the system, the cathodic reaction that takes place is shown in (2):

$$
2 \mathrm{H}^{+}+\frac{1}{2} \mathrm{O}_{2}+2 e^{-} \longrightarrow \mathrm{H}_{2} \mathrm{O}
$$

The hydrogen ion is present in water due to the ubiquitous dissolution of water into hydroxyl ions as shown in (3):

$$
2 \mathrm{H}_{2} \mathrm{O} \longrightarrow 2 \mathrm{H}^{+}+2(\mathrm{OH})^{-}
$$

In the anode, there is a dissociation of iron to form a ferrous ion as shown in (4).

$$
\mathrm{Fe} \longrightarrow \mathrm{Fe}^{2+}+2 \mathrm{e}^{-}
$$

The ferrous ion will react with the hydroxyl ion to form insoluble ferrous hydroxide as shown in (5):

$$
\mathrm{Fe}^{2+}+2(\mathrm{OH})^{-} \longrightarrow \mathrm{Fe}(\mathrm{OH})_{2}
$$

The anodic and cathodic reactions that take place in a neutral and alkaline condition is shown in Figure 3.

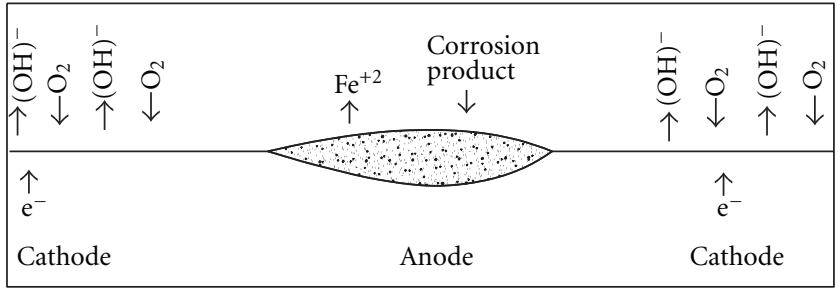

FIgURE 3: Neutral and Alkaline condition of a corrosion process.

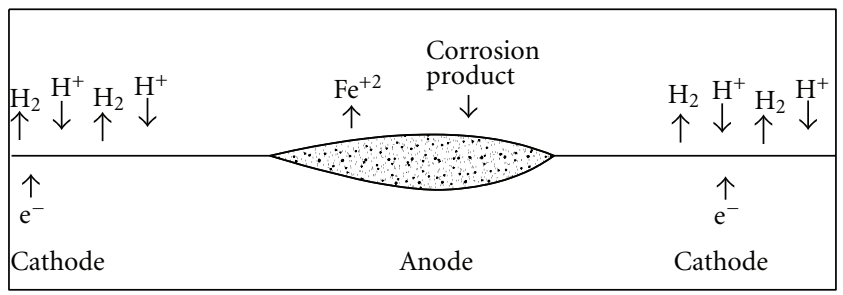

FIgURE 4: Acidic Condition of a Corrosion process.

The cathodic reaction is as follows:

$$
\frac{1}{2} \mathrm{O}_{2}+\mathrm{H}_{2} \mathrm{O}+2 \mathrm{e}^{-} \longrightarrow 2(\mathrm{OH})^{-}
$$

while the anodic reaction is the same as (4).

For an anodic condition, the cathodic and anodic reactions are represented in Figure 4.

The cathodic reaction equation is shown in (1), while the anodic equation is shown in (4).

In a deoxygenated solution, the hydrogen reaction combines with the others to yield the net corrosion reaction shown in (7):

$$
\mathrm{Fe}+2 \mathrm{H}_{2} \mathrm{O} \longrightarrow \mathrm{Fe}(\mathrm{OH})_{2}+\mathrm{H}_{2}(\mathrm{~g})
$$

In oxygenated aqueous systems, the oxygen reduction leads to a slightly different net corrosion reaction as shown in (8):

$$
\mathrm{Fe}+\mathrm{H}_{2} \mathrm{O}+\frac{1}{2} \mathrm{O}_{2} \longrightarrow \mathrm{Fe}(\mathrm{OH})_{2}
$$

Whereas in deoxygenated solution, hydrogen is evolved, in oxygenated system, oxygen is consumed. The evolved hydrogen acts as a catalyst for the formation of magnetite $\left(\mathrm{Fe}_{3} \mathrm{O}_{4}\right)$ in deoxygenated water. Experiment shows that hydroxide readily decomposes into magnetite in deoxygenated water above $100^{\circ} \mathrm{C}[28]$ as indicated in (9):

$$
3 \mathrm{Fe}(\mathrm{OH})_{2} \longrightarrow \mathrm{Fe}_{3} \mathrm{O}_{4}+\mathrm{H}_{2}(\mathrm{~g})+2 \mathrm{H}_{2} \mathrm{O}
$$

The net corrosion reaction with the magnetite as the final product is shown in (10):

$$
3 \mathrm{Fe}+4 \mathrm{H}_{2} \mathrm{O} \longrightarrow \mathrm{Fe}_{3} \mathrm{O}_{4}+4 \mathrm{H}_{2}(\mathrm{~g})
$$

In oxygenated solution, the ferrous oxide $\left(\mathrm{Fe}^{2+}\right)$ does not immediately precipitate out since it rapidly oxidizes to ferric oxide $\left(\mathrm{Fe}^{3+}\right)$, as a result, insoluble iron hydroxide is formed which is converted to hematite as shown in (11):

$$
\mathrm{Fe}(\mathrm{OH})_{2}+\frac{1}{2} \mathrm{H}_{2} \mathrm{O}+\frac{1}{4} \mathrm{O}_{2} \longrightarrow \mathrm{Fe}(\mathrm{OH})_{3}
$$


The ferric oxide $\left(\mathrm{Fe}^{3+}\right)$ is converted to magnetite according to $(12)$

$$
2 \mathrm{Fe}(\mathrm{OH})_{3}+\mathrm{Fe}(\mathrm{OH})_{2} \longrightarrow \mathrm{Fe}_{3} \mathrm{O}_{4}+4 \mathrm{H}_{2} \mathrm{O}
$$

Cathodic and anodic sites could be built as a result of variation in environmental conditions, metallic microstructure variation, and variation in environmental concentration of oxygen at different points of a metal [26]. At the anodic sites, the dissolution of metallic ions in the electrolyte brings about the flow of electrons between the corroding anodes and noncorroding cathodes. The spontaneous nature of the corrosion however, depends on the rate of flow of these electrons.

Though establishing the tendency for corrosion is necessary, however, it is more important to determine the rate of corrosion. This is because a particular metal or alloy may be prone to corrosion in an environment but at a very low rate, in which it will not be a problem [26]. To understand the rate of corrosion however, requires the knowledge of the role of primary environment and metallurgical variables, underlying mechanism of corrosion, and synthesis of information to account for effects of the parameters.

\section{Mechanisms of Corrosion in Oil and Gas Pipelines}

Fluid flowing from oil and gas pipelines has a combination of chemicals including $\mathrm{CO}_{2}, \mathrm{H}_{2} \mathrm{~S}$, organic acids, bacteria, sand, and water. These constituents are among the major causes of corrosion in pipeline. The $\mathrm{CO}_{2}$ dissolves in the presence of water to form an acidic oxide which reacts with iron. This type of corrosion is referred to as sweet corrosion. This is responsible for most types of general corrosion in oil and gas pipeline. Sour corrosion occurs when $\mathrm{H}_{2} \mathrm{~S}$ in the excess of $100 \mathrm{ppm}$ is present in the oil and gas, causes corrosion in the pipeline, and predominantly causes pitting [26, 29].

$\mathrm{CO}_{2}$ present in oil and gas will dissolve in water to produce carbonic acid $\left(\mathrm{H}_{2} \mathrm{CO}_{3}\right)[23,27]$. This acid dissolves steel to produce iron carbonate and hydrogen as shown in (13). This reaction takes place at the cathode:

$$
\mathrm{Fe}+\mathrm{H}_{2} \mathrm{CO}_{3} \longrightarrow \mathrm{FeCO}_{3}+\mathrm{H}_{2}(\mathrm{~g})
$$

Despite the weakness of carbonic acid it is extremely corrosive to carbon steel. The chemical reactions above form the iron carbonate films. Depending on the condition during the formation, these films can be protective or nonprotective at the anode, iron dissolves as shown in (4). The presence of $\mathrm{CO}_{2}$ acts as a catalyst increasing the hydrogen evolution thereby increasing the corrosion rate of carbon steel in aqueous solution [27]. The carbonic acid $\left(\mathrm{H}_{2} \mathrm{CO}_{3}\right)$ either serves as an extra source of $\mathrm{H}^{+}$or is reduced directly according to (14) and (15):

$$
\begin{gathered}
2 \mathrm{H}^{+}+2 \mathrm{e}^{-} \longrightarrow \mathrm{H}_{2}(\mathrm{~g}) \\
2 \mathrm{H}_{2} \mathrm{CO}_{3}+2 \mathrm{e}^{-} \longrightarrow \mathrm{H}_{2}(\mathrm{~g})+2 \mathrm{HCO}_{3}^{-}
\end{gathered}
$$

The dissolved iron concentration will increase until $\mathrm{Fe}^{2+}$ is the same as the precipitation rate of $\mathrm{FeCO}_{3}[30]$. When $\mathrm{Fe}^{2+}$

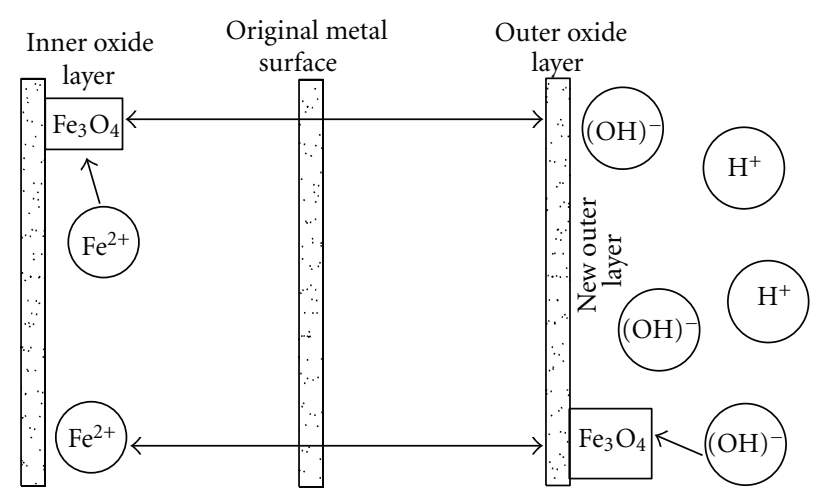

Figure 5: Schematic of magnetite double layer showing oxide formation locations.

is released in the corrosion process, the double amount of bicarbonate forms according to (16):

$$
\mathrm{Fe}+2 \mathrm{H}_{2} \mathrm{CO}_{3} \longrightarrow \mathrm{Fe}^{2+}+\mathrm{H}_{2}+2 \mathrm{HCO}_{3}{ }^{-}
$$

The $\mathrm{pH}$ increases until bicarbonate and carbonate becomes so high that solid $\mathrm{FeCO}_{3}$ precipitates [30] as shown in equation (17):

$$
\mathrm{Fe}^{2+}+2 \mathrm{HCO}_{3}^{-} \longrightarrow \mathrm{FeCO}_{3}(\mathrm{~s})+\mathrm{H}_{2} \mathrm{CO}_{3}
$$

When all the ferrous ions produced by corrosion precipitates as iron carbonate $\left(\mathrm{FeCO}_{3}\right)$, the $\mathrm{pH}$ remains constant and the overall reaction becomes as the state in (13).

In order to control the rate of corrosion on the pipeline, there should be passivity. Passivity is the condition existing on a metal surface because of the presence of protective film. When protective film is formed on the metal surface, it forms a coat which hinders further corrosion action on the material $[26,31]$. The structure of the passive film (magnetite) formed on low carbon steel oxidizes in high temperature and has two distinct layers on the steel. The inner layer is compact and adheres well to the steel and has uniform thickness. The outer layer is a porous mass of individual crystal that would flake off the steel in some place and very nonuniform in thickness (Figure 5). This protective film is removed from the surface of the pipeline through erosion, dissolution, and turbulence resulting in more corrosion. The possible mechanisms resulting in the removal of the protective film are a follows:

(i) Dissolution or removal of protective layer by hydrodynamic shear stress occurs when the shear stress is greater than the bonding force between the film and the substrate. This is a function of a mechanical process of erosion caused by the multiphase flow regime in pipeline [19, 32].

(ii) In distributed flow condition, local near wall density of turbulence helps to remove the protective film. This disruption to the mass transfer boundary layer results in an enhanced corrosion rate [32,33].

(iii) Dissolution of film which is controlled by mass transfer. Thus the breakaway velocity may reflect conditions where the dissolution rate of the film is greater than the growth rate of the film [34]. 
The breakdown of protective film leads to the formation of localized corrosion that results in some of the major sources of corrosion failures like pitting, crevice, intergranular, and stress corrosion $[12,26,35,36]$. The predominant breakdown processes are electrochemical and mechanical. Mechanical breakdown occurs when the protective film is ruptured as a result of stress or abrasive wear while, the electrochemical breakdown is a function of chemical reaction between the fluid constituent and the steel.

\subsection{Types of Corrosion in Oil and Gas Pipeline. The primary} chemical components that cause corrosion reaction to occur in pipeline are oxygen, acidic sulphur, and acidic chloride that dissolves in the water in the pipeline. The mechanism present in a given piping system varies according to the fluid composition, service location, geometry, temperature and so forth. In all cases of corrosion, the electrolyte must be present for the reaction to occur.

3.1.1. Internal Corrosion. Internal corrosion has become an increasing problem in most oil and gas pipelines as water cuts have increased and previously oil wet pipe surfaces have become water wet (providing the electrolyte for the corrosion cell) and as bacterial activities increases in the production system. Internal corrosion is the largest cause of pipeline failure in oil and gas industries [24] through different forms of corrosion like microbiologically influenced corrosion (MIC), erosion (flow enhanced) corrosion, under deposit (concentration cell) corrosion and so forth.

Erosion-Corrosion. The erosion-corrosion mechanism increases corrosion reaction rate by continuously removing the passive layer of corrosion products from the wall of the pipe. The passive layer is a thin film of corrosion product that actually serves to stabilize the corrosion reaction and slow it down. As a result of the turbulence and high shear stress in the line, this passive layer can be removed causing the corrosion rate to increase [37]. The erosion-corrosion is always experienced where there is high turbulence flow regime with significantly higher rate of corrosion than just corrosion or erosion in pipeline [38]. In a multiphase flow regime with a fully developed turbulent flow, bubbles development and collapse have been attributed to changes in mass transfer coefficient and an eventual increase in $\mathrm{CO}_{2}$ corrosion in pipeline [34].

Under Deposit Corrosion. The under deposit mechanism can increase the corrosion reaction rate by causing a localized chemical concentration which results in pitting of the metal surface under solid deposits. These deposits appear to be composed of a corrosion product matrix with entrapment of formation solids, sand, and iron sulphide. The rate of corrosion under this mechanism is significantly lower than erosion-corrosion mechanism.

Microbiologically Induced Corrosion (MIC). This type of corrosion is caused by bacterial activities. The bacteria produce waste products like $\mathrm{CO}_{2}, \mathrm{H}_{2} \mathrm{~S}$ and organic acids that corrode the pipes by increasing the toxicity of the flowing fluid in the pipeline. Some bacteria like sulphate removing bacteria (SRB) consume hydrogen that is a product in a standard corrosion reaction process. This activity causes the existing corrosion rate to increase in an attempt to reach reaction equilibrium by replacing the hydrogen consumed by bacteria. Bacteria also accumulate on the pipe walls, creating deposits and under deposit corrosion. MIC is recognized by the appearance of black slimy waste material or nodules on the pipe surface as well as pitting of the pipe wall underneath these deposits.

Pitting Corrosion. Pitting is classified as a localized attack that results in rapid penetration and removal of metal at small discrete area. The initiation of a pit occurs when electrochemical or chemical breakdown exposes a small local site on a metal surface to damaging species such as chloride ion. The site where pitting occurs is where there is an environmental variation in comparison to the entire metal surface. The combination of chlorine with $\mathrm{H}_{2} \mathrm{~S}$ results in localized pitting on steel [35]. This area of pitting which is usually the anode normally get highly degraded due to enormous electron transfer between the entire large area of the metal surface which is the cathode and small anode (the pitting site).

Crevice Corrosion. Crevice corrosion results when a portion of a metal surface is shielded in such a way that the shielded portion has limited access to the surrounding environment. Such surrounding environment contain, damaging corrosion species usually chloride ion. A typical example of crevice corrosion is the crevice found at the area between two metal surfaces in close contact with a gasket or another metal surface. The environment that eventually forms in the crevice is similar to that formed under the precipitated corrosion that covers a pit. An electrochemical corrosion cell is formed from the couple between the unshielded surface and the crevice interior exposed to an environment with a lower oxygen concentration compared with the surrounding medium. The concentration of being the anode of a corrosion cell and existing in an acidic, high-chloride environment where repassivation is difficult makes the crevice interior subject of corrosion attack.

Stress Corrosion Cracking (SCC). Stress corrosion cracking (SCC) is a form of localized corrosion which produces cracks in metals by simultaneous action of a corrodent and tensile stress. It propagates over a range of velocities from $10^{-3}-10 \mathrm{~mm} / \mathrm{h}$ depending upon the combination of alloy and environment involved. The geometry is such that if they grow to appropriate lengths, they may reach a critical size that results in a transition from the relatively slow crack growth rate associated with stress corrosion to fast crack propagation rates associated with purely mechanical failure. This transition happens when the stress intensity, which is a function of the geometry of the component including the crack size, reaches the fracture value for the material concerned. SCC in pipeline is a type of environmentally associated cracking (EAC). This is because the crack is 
caused by various factors combined with the environment surrounding the pipe. The most obvious identifying characteristic of SCC in pipeline is high $\mathrm{pH}$ of the surrounding environment, appearance of patches, or colonies of parallel cracks on the external of the pipe [39].

Top of the Line Corrosion (TLC). This type of corrosion occurs due to the inability of corrosion inhibitors getting to the top of the pipeline ( 12 o'clock) thereby exposing it to corrodents. The inhibition effect is found to be predominant at the bottom of the line ( 6 o'clock), 9 o'clock and 3 o'clock where the flow of the oil or gas is taking place. This exposes the top of the line to concerted attack by the agents of corrosion with a resultant failure at some point. The primary factor that affects TLC is temperature which acts on the iron carbonate film formed. The combined effect of temperature fluctuation and condensation rate exposes the iron carbonate film to deterioration and consequently more corrosion. A study of the influence of gas flow rate on TLC shows that higher flow rate (which results in higher condensation rate) brings about more corrosion [40], while at a certain critical condensation rate, temperature and $\mathrm{pH}$, TLC does not occur in gas pipelines [41]. The presence of acetic acid (HAc) has been found to enhance $\mathrm{CO}_{2}$ TLC on carbon steel pipe, though at certain concentration level, HAc does not affect $\mathrm{CO}_{2}$ TLC in carbon steel [42].

3.1.2. External Corrosion. External corrosion is caused by water penetrating the insulation system and is trapped between the insulation and the external pipe wall. The corrosion cell is fuelled by the continual supply of water and oxygen from the external sources. The main area where external corrosion is found is at the field applied weld insulation packs, but it can also be at any location where the galvanized insulation jacket has been punctured or torn. Weld pack insulations that are not well sealed allow water ingress making the weld packs to be wet. A fairly high temperature is needed to drive the corrosion mechanism, and the longer the mechanism has been active, the worst the damage will be. Therefore, the hottest and coldest lines in the field should have the highest likelihood for having an external corrosion problem.

\section{Corrosion Management Techniques}

Corrosion management is that part of the overall management system, which is concerned with the development, implementation, review, and maintenance of corrosion policy [7]. The corrosion policy, however, is a framework on which decision concerning corrosion issue in an industrial setting is based. This framework provides basic measures for risk determination via development of absolute risk control measures through planning, implementation, and control strategies. Corrosion management contributes to numerous benefits like statutory or corporate compliance with safety, health and environment policies, reduction in leaks, increased plant availability, reduced unplanned maintenance, and reduction in deferment costs [43]. To

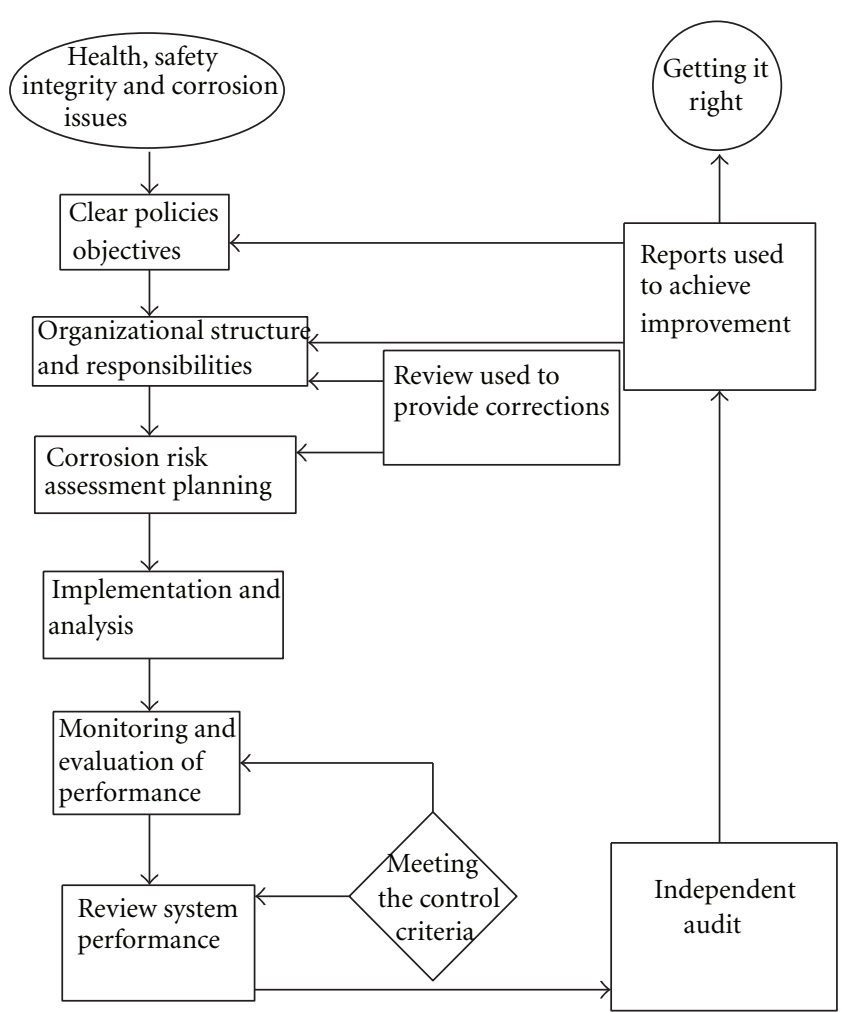

Figure 6: Corrossion management framework.

manage corrosion involves the utilization of a framework that will model the organization's policy through organizing, planning and implementing, measuring and reviewing, and auditing performance at all levels of execution as shown in Figure 6.

4.1. Corrosion Risk Assessment (CRA). In planning for corrosion management, there is need for a formal identification of facilities that have the risk of degradation due to corrosion. The purpose of corrosion risk assessment is to rank facilities in order of their proneness to corrosion, identify options to remove, mitigate, or manage the risks. In order to manage corrosion risks, monitoring and inspection program will be incorporated in the overall activity schedule of an organization. The probability of failure is estimated based on the type of corrosion damage expected to occur on the component while the consequences of failure are measured against the impact of such a failure evaluated against a number of criteria. The criteria could include potential hazards to environment, risks associated with safety and integrity, or risk due to corrosion or inadequate corrosion mitigation procedure.

Typical of the risk-based procedure is the Failure Mode, Effect and Critical Analysis (FMECA) that ranks perceived risks in order of seriousness as shown in (18):

$$
\begin{aligned}
& \text { Criticality (Risk) } \\
& \text { = Effect (Consequences) } * \text { Mode (Probable Frequency), }
\end{aligned}
$$


TABLE 1: Safety class and target annual failure probability.

\begin{tabular}{lc}
\hline Safety class & Annual failure probability \\
\hline High & $<10^{-3}$ \\
Medium & $<10^{-4}$ \\
Low & $<10^{-5}$ \\
\hline
\end{tabular}

where: failure Criticality is potential failures as examined in order to predict the severity of each failure effect in terms of safety, decreased performance, total loss of function and environmental hazards. Failure effect is potential failures assessed to determine the probable effect on process performance and the effects of the components on each other. Failure mode is the anticipated operational conditions used to identify most probable failure mode, the damage mechanism and likely locations.

Corrosion risk is the product of the probabilities of a corrosion-related failure and the consequences of such a failure [44]. The risk analysis of a pipeline is a measure of the probability of failure. The acceptable annual failure probability is dependent on the safety class [45] as shown in Table 1.

Corrosion risk assessment can be carried out on a group of components which are constructed from the same material and subject to the same operating condition or an individual component. In oil and gas pipelines, the risk is analysed as either external or internal corrosion threat or environmental and operational threat. The remaining life of the pipeline is estimated against some established operational standards, while the rate of corrosion is correlated with the operating parameters of the oil and gas like $\mathrm{CO}_{2}$, $\mathrm{H}_{2} \mathrm{~S}$, temperature, pressure, flow rate, water cut and so forth. For effective corrosion assessment, the information concerning the operating condition of a facility will be maintained throughout the life cycle. The information is useful in formulating a corrosion risk assessment model that will be validated and modified with new assumptions overtime. For a non stable process condition, detailed reassessment will be required at least annually but a stable process with good historical data trend will need revalidation less frequently [7].

4.2. Risk Based Inspection (RBI). In managing oil and gas pipelines against corrosion, RBI technique is used to develop an optimum plan for the execution of the inspection activities. RBI uses findings from corrosion risk assessment (CRA) or other risk analysis to plan physical inspection procedures. A risk-based approach to inspection planning will ensure that risk is reduced to as low as reasonably practicable. It will also optimize inspection schedule, focus effort on the most critical area, and identify the most appropriate methods of inspection [46]. Planning a riskbased analysis involves listing activities, task and other elements of a project, identifying the technical risks, develop a risk ranking factor scale for each activity, document results and identify potential risks reduction actions for evaluation by personnel [47].
TABLE 2: Summary of corrosion monitoring techniques.

\begin{tabular}{ll}
\hline Direct method & Indirect method \\
\hline Non-destructive inspection (NDI) & Biological counts \\
Material test coupons & Hydrogen probes \\
Electrical resistance (ER) probes & $\mathrm{pH}$ probes \\
Linear polarization resistance (LPR) & Specific ions \\
Elector-chemical impedance & Temperature \\
spectroscopy (EIS) & conductivity \\
Electro-chemical noise (EN) & Electrical potential monitor \\
Galvanic current (GC) &
\end{tabular}

4.3. Corrosion Monitoring. Corrosion inspection and monitoring are key activities in ensuring, pipelines integrity are maintained and corrosion mitigated [48]. The choice of corrosion control measure is a function of fluid composition, pressure, temperature, aqueous fluid corrosivity, facility, and technical culture inherent in an establishment. In monitoring and inspection of pipelines, data are collected to enhance corrosion control by way of predicting the remaining life and the suggestion of possible mitigation measures that will help to enhance serviceability will largely depend on the experience of the personnel. A thorough practice for corrosion management involves the monitoring of corrosion risks through proactive and reactive monitoring techniques. In management of pipeline corrosion in oil and gas industries, proactive technique which involves determination of the corrosion standpoint prior to failure is utilized. This involves in-line and on-line monitoring system. In this system, data which could enhance the knowledge of the rate of corrosion degradation are collected and steps are taken to prevent failure. In-line system cover the installation of devices directly into the pipeline like corrosion coupons, biostuds and so forth. These need to be extracted for analysis periodically. On-line monitoring techniques include deployment of corrosion monitoring devices either directly into the process or fixed permanently to the facility. These include electrical resistance (ER) probes, linear polarization resistance (LPR) probes, fixed ultrasonic (UT) probes, acoustic emission and so forth.

Whereas some corrosion monitoring techniques can be used for continuous monitoring, others are used for periodic monitoring. Corrosion monitoring techniques can either be direct or indirect parameter measure. This is summarized in Table 2.

4.4. Corrosion Mitigation Strategies. After corrosion risk assessment and data collection and analysis are completed, there is need for corrective action on the facility; this depends on the level of the deterioration experienced by facility. The approaches available for mitigating corrosion in pipeline includes, coating surfaces to act as a barrier or perhaps provide sacrificial protection, the addition of chemical specie to the environment to limit corrosion, alteration of alloy chemistry to make it more resistance to corrosion and utilization of alternative material [24]. 
TABLE 3: Shows the different pipeline corrosion mitigation strategies.

\begin{tabular}{|c|c|c|}
\hline Mitigation strategy & Option & Remarks \\
\hline Appropriate materials & $\begin{array}{l}\text { Use of corrosion resistant alloys, non-metallic materials } \\
\text { like Reinforced composite, thermoplastic-lined and } \\
\text { polyethylene pipelines. Consider use of internally } \\
\text { coated carbon steel pipeline systems (i.e., nylon or } \\
\text { epoxy coated) with an engineered joining system. }\end{array}$ & $\begin{array}{l}\text { (i) Non-metallic materials may be used as a liner or a } \\
\text { free standing pipeline depending on the service } \\
\text { conditions. } \\
\text { (ii) Selection of appropriate material at construction } \\
\text { and major refurbishment stage is necessary. }\end{array}$ \\
\hline Chemical treatment & $\begin{array}{l}\text { Corrosion inhibitors, biocides, oxygen scavengers, gas } \\
\text { blanketing, vacuum deaeration }\end{array}$ & $\begin{array}{l}\text { (i) The presence of small amounts of oxygen (parts per } \\
\text { billion) or bacteria will accelerate corrosion. } \\
\text { (ii) Provides a barrier between corrosive elements and } \\
\text { the pipe surface }\end{array}$ \\
\hline Coating and lining & Organic Coatings, metallic coatings, lining, cladding & Useful for internal and external corrosion prevention \\
\hline Cathodic protection & $\begin{array}{l}\text { Sacrificial anodes, impressed current systems, hybrid } \\
\text { system }\end{array}$ & Need ability to monitor performance on-line. \\
\hline Process control & $\begin{array}{l}\text { Identify key parameters: } \mathrm{pH} \text {, temperature, pressure, } \\
\text { Flow rate, water chemistry, } \mathrm{pH} \text {, chlorides, dissolved } \\
\text { metals, bacteria, suspended solids, chlorine, oxygen, } \\
\text { and chemical residuals }\end{array}$ & $\begin{array}{l}\text { (i) Changes in operating conditions will influence the } \\
\text { corrosion potential. Production information can } \\
\text { be used to assess corrosion susceptibility based on } \\
\text { fluid velocity and corrosivity } \\
\text { (ii) Trends in dissolved metal concentration (i.e., Fe, } \\
\text { Mn) can indicate changes in corrosion activity }\end{array}$ \\
\hline Design detailing & $\begin{array}{l}\text { Ensure ease of access and replacement: } \\
\text { (i) Install valves that allow for effective isolation of } \\
\text { pipeline segments from the rest of the system } \\
\text { (ii) Install binds for effective isolation of in-active } \\
\text { pipeline segments }\end{array}$ & $\begin{array}{l}\text { Allows the effective suspension and discontinuation of } \\
\text { pipeline segments: } \\
\text { (i) Removes potential "deadlegs" from the gathering } \\
\text { system } \\
\text { (ii) Develop shut-in guidelines for the timing of } \\
\text { required steps to isolate and lay up pipelines in each } \\
\text { system }\end{array}$ \\
\hline
\end{tabular}

TABLE 4: Corrosion inhibitor risk categories.

\begin{tabular}{|c|c|c|c|c|}
\hline Risk category & $\begin{array}{c}\text { Max inhibitor } \\
\text { availability }\end{array}$ & $\begin{array}{l}\text { Max expected uninhibited } \\
\text { corrosion rate }(\mathrm{mm} / \mathrm{yr})\end{array}$ & comments & $\begin{array}{c}\text { Proposed category } \\
\text { name }\end{array}$ \\
\hline 1 & $0 \%$ & ( & $\begin{array}{l}\text { Benign Fluid, corrosion inhibitor use not } \\
\text { anticipated. Predicted metal loss accommodated by } \\
\text { corrosion allowance }\end{array}$ & Benign \\
\hline 2 & $50 \%$ & 0.7 & $\begin{array}{l}\text { Corrosion inhibitor probably required but with } \\
\text { expected corrosion rates there will time be time to } \\
\text { review the need for inhibition based on inspection } \\
\text { data. }\end{array}$ & Low \\
\hline 3 & $90 \%$ & 3 & $\begin{array}{l}\text { Corrosion inhibition required for majority of field } \\
\text { life but inhibitor facilities need not be available from } \\
\text { day one. }\end{array}$ & Medium \\
\hline 4 & $95 \%$ & 6 & $\begin{array}{l}\text { High reliance on inhibition for operational life time. } \\
\text { Inhibitor facilities most be available from day one to } \\
\text { ensure success }\end{array}$ & High \\
\hline 5 & $>95 \%$ & $>6$ & $\begin{array}{l}\text { Carbon steel and inhibition is unlikely to provide } \\
\text { integrity for full field life. Select corrosion resistant } \\
\text { material or plan for repair and replacement }\end{array}$ & Unacceptable \\
\hline
\end{tabular}

Effective corrosion mitigation involves a good approach to assessment linked to inspection monitoring during initial design and re-evaluation of pipeline with respect to the selection of inhibitors. The summary of inhibitor selection for carbon steel pipeline at different risk categories is shown in Table 4.

Corrosion can be prevented or controlled by understanding the principle underlying corrosion process. This understanding has been the basis for the development of a number of corrosion prevention measures. The basic corrosion control measures are based on electrochemical driving force as shown in Pourbaix diagram in Figure 7. Table 3 shows the different pipeline corrosion mitigation strategies.

\section{Conclusions}

The prevalence of corrosion in oil and gas industry has resulted in enormous investment in technology to help 


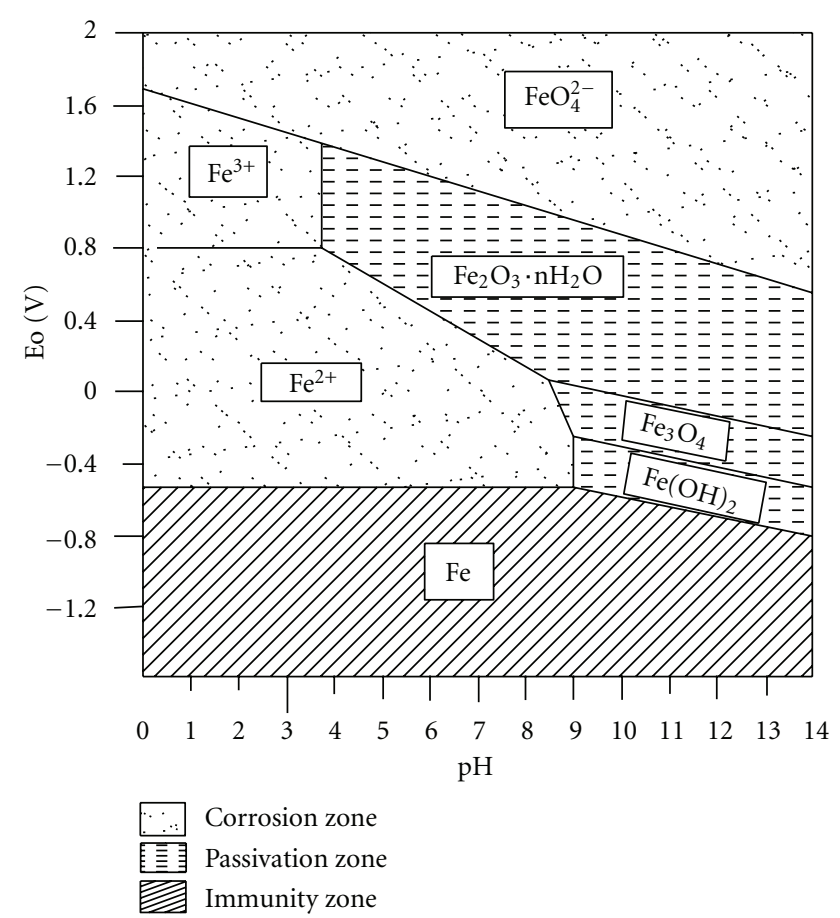

Figure 7: Pourbaix diagram of iron corrosion, passivity and immunity.

combat impacts like loss of containment, leakages, death of personnel an environmental pollution. To this end, new oil and gas fields are developed using experiences generated from previous fields with similar characteristics. Efforts of design personnel at ensuring that the carbon steel materials are operating in the environment of immunity or passivity as shown in Pourbaix diagram (Figure 7) are yielding results via introduction of high corrosion resistant carbon alloys for pipelines. In other instances, specialized corrosion resistant materials have been used for lining the pipelines while reinforced composite and PVC materials have been utilized as alternative material for pipeline construction.

Advancements in inspection and monitoring techniques are also aiding corrosion experts in decision concerning the "when" and "how" pipelines are managed in a bid to optimize performance and cost. The proliferation of different empirical, statistical, and mechanistic prediction models for corrosion prediction is aiding personnel in managing the integrity of the pipelines through different mitigation strategies.

Finally, if pipeline corrosion which is a major contributor to nonproductive time (NPT) in oil and gas production will be reduced to the barest minimum, a corrosion management policy with a well-defined structure that includes responsibilities, reporting routes, practices, procedures, and resources has to be strictly followed in the oil and gas industries. The effectiveness of the policy will therefore depend on the willing of the leadership and commitment of other personnel at all ranks.

\section{References}

[1] R. Nicholson, J. Feblowitz, C. Madden, and R. Bigliani, "The Role of Predictive Analytics in Asset Optimization for the Oil and Gas Industry-White Paper," 2010, http://www.tessella .com/wp-content/uploads/2008/02/IDCWP31SA4Web.pdf.

[2] J. Neelamkavil, "A review of Existing Tools and Their Applicability to Maintenance Management. Report \# RR-285," http://pdf.aminer.org/000/274/575/a_decision_support_system_for_transmission_facility_maintenance.pdf.

[3] Oil and Gas Enhanced Production Services Industry to 2016-Enhanced Oil Recovery (EOR) Driving E\&P Activity in Depleting Hydrocarbon Reservoirs, http://www.reportlinker .com/p0845623/Oil-and-Gas-Enhanced-Production-ServicesIndustry-to-Enhanced-Oil-Recovery-EOR-Driving-E-P-Activity-in-Depleting-Hydrocarbon-Reservoirs.html.

[4] Control of Major Accident Hazards, "Ageing Plant Operational Delivery Guide," http://www.hse.gov.uk/comah/guidance/ageing-plant-core.pdf.

[5] P. Horrocks, D. Mansfield, K. Parker, J. Thomson, T. Atkinson, and J. Worsley, "Managing Ageing Plant," http://www.hse .gov.uk/research/rrpdf/rr823-summary-guide.pdf.

[6] "Cost of Corrosion to Exceed \$1 Trillion in the United States in 2012-G2MT Labs - The Future of Materials Condition Assessment," http://www.g2mtlabs.com/2011/06/nace-cost-of -corrosion-study-update/.

[7] Review of Corrosion Management for Offshore Oil and Gas Processing, HSE OffshoreTechnology Report 2001/044, 2001.

[8] Corrosion in the Oil Industry(Oilfield review) Schlumberger, http://www.slb.com/resources/publications/industry_articles/ oilfield_review/1994/or19940401_corrosion.aspx.

[9] B. Khajota, D. Sormaz, and S. Nesic, "Case-based reasoning model of $\mathrm{CO}_{2}$ corrosion based on field data," CORROSION, 2007, paper no. 07553.

[10] K. U. Raju, "Successful scale mitigation strategies in Saudi Arabian oil fields," in International Symposium on Oilfield Chemistry, The Woodlands, Tex, USA, April 2009, paper no. 121679.

[11] A. Darwin, K. Annadorai, and K. Heidersbach, "Prevention of corrosion in carbon steel pipeline containing hydrostatic water- an overview," in CORROSION, March 2010, paper no. 10401 .

[12] J. Wen, T. Gu, and S. Nesic, "Investigation of the effects of fluid flow on SRB biofilm," in CORROSION, 2007, Paper no. 07516.

[13] B. Hedges, H. J. Chen, T. H. Bieri, and K. Sprague, "A review of monitoring and inspection technique for $\mathrm{CO}_{2}$ and $\mathrm{H}_{2} \mathrm{~S}$ corrosion in oil and gas production facilities: location, location, location," in CORROSION, 2006, paper no. 06120.

[14] M. Singer, B. Brown, A. Camacho, and S. Nešić, "Combined effect of carbon dioxide, hydrogen sulfide, and acetic acid on bottom-of-the-line corrosion," Corrosion, vol. 67, no. 1, 2011.

[15] K. L. J. Lee and S. Nesic, "EIS investigation of $\mathrm{CO}_{2} / \mathrm{H}_{2} \mathrm{~S}$ corrosion," in CORROSION, April 2004, paper no. 04728.

[16] K. D. Ralston and N. Birbilis, "Effect of grain size on corrosion: a review," Corrosion, vol. 66, no. 7, pp. 0750051-07500513, 2010.

[17] Y. Song, A. Palencsár, G. Svenningsen, J. Kvarekvål, and T. Hemmingsen, "Effect of $\mathrm{O}_{2}$ and temperature on sour corrosion," Corrosion, vol. 68, no. 7, pp. 662-671, 2012.

[18] A. Kale, B. H. Thacker, N. Sridhar, and C. J. Waldhart, "A probabilistic model for internal corrosion of gas pipelines," in Proceedings of the 5th Biennial International Pipeline Conference (IPC'04), pp. 2437-2445, Calgary, Canada, October 2004. 
[19] S. Nesic, J. Cai, and K.-L. J. Lee, "A multiphase flow and internal corrosion prediction model for mild steel pipeline," in CORROSION, 2005, Paper no. 05556.

[20] W. Sun and S. Nesic, "A mechanistic model of $\mathrm{H}_{2} \mathrm{~S}$ corrosion of mild steel," in CORROSION, 2007, paper no. 07655.

[21] X. Hu, V. D. Souza, A. Neville, and J. Well, "Prediction of erosion-corrosion in oil and gas- a systematic approach," in CORROSION, 2008, paper no. 08540.

[22] X. Tang, C. Li, F. Ayello, J. Cai, and S. Nesic, "Effects of oil type on phase wetting transition and corrosion in oil-water flow," in CORROSION, NACE International, 2007, Paper no. 017170.

[23] Y. Xian and S. Nesic, "A stochastic prediction model of localized $\mathrm{CO}_{2}$ corrosion," in CORROSION, 2005, paper no. 05057.

[24] CAPP, "Best Management Practices: Mitigation of Internal Corrosion in Oil Effluent Pipeline Systems," 2009, http:// www.capp.ca/getdoc.aspx?DocId=155641\&DT $=$ PDF.

[25] B. A. Shaw and R. G. Kelly, "What is corrosion?" Electrochemical Society Interface, vol. 15, no. 1, pp. 24-26, 2006.

[26] J. Kruger, "Electrochemistry of Corrosion," 2001, http:// electrochem.cwru.edu/encycl/art-c02-corrosion.htm.

[27] V. Fajardo, C. Canto, B. Brown, and S. Nesic, "Effect of organic acids in $\mathrm{CO}_{2}$ corrosion," in Proceedings of the NACE International Conference and Exposition CORROSION, 2007, paper no. 07319.

[28] P. S. Joshi, G. Venkateswaran, K. S. Venkateswarlu, and K. A. Rao, "Stimulated decomposition of $\mathrm{Fe}(\mathrm{OH})_{2}$ in the presence of AVT chemicals and metallic surfaces-relevance to lowtemperature feedwater line corrosion," CORROSION, vol. 49, no. 4, pp. 300-309, 1993.

[29] R. Nyborg, "Controlling internal corrosion in oil and gas pipeline," Business Briefing-Exploration \& Production: The Oil \& Gas Review, no. 2, pp. 70-74, 2005.

[30] A. Dugstad, E. Gulbrandsen, M. Seiersten, J. Kvarekval, and R. Nyborg, "Corrosion testing in multiphase flow, challenges and limitations," in CORROSION, 2006, paper no 06598.

[31] R. N. Kig, "A review of fatigue crack growth in air and seawater," Offshore Technology Report OTH96 511, HSE, 1996.

[32] A. Keating and S. Nesic, "Prediction of two-phase erosioncorrosion in bends," in Proceedings of the 2nd International Conference on CFD in Minerals and Processes Industries CSIRO, Melbourne, Australia, December 1999.

[33] S. Nesic and J. Postlethwaite, "Relationship between the structure of disturbed flow and erosion-corrosion," Corrosion, vol. 46, no. 11, pp. 874-880, 1990.

[34] H. Wang, W. Paul Jepson, J.-Y. Cai, and M. Gopal, "Effect of bubbles on mass transfer in multiphase flow," in CORROSION, 2000, paper no. 00050 .

[35] H. Fang, B. Brown, and S. Nešiæ, "Effects of sodium chloride concentration on mild steel corrosion in slightly sour environments," in CORROSION, vol. 67, no. 1, January 2011.

[36] E. Mysara Mohyaldinn, N. Elkhatib, and C. Mokhtar Ismail, "A computational tool for erosion/corrosion prediction in Oil/Gas production facilities," in Proceedings of $3 \mathrm{rd}$ International Conference on Solid State Science \& Technology (ICSSST'10), Kuching, Malaysia, December 2010.

[37] Sh. Hassani, K. P. Roberts, S. A. Shirazi, J. R. Shadley, E. F. Rybicki, and C. Joia, "Flow loop study of $\mathrm{NaCl}$ concentration effect on erosion, corrosion, and erosion-corrosion of carbon steel in $\mathrm{CO}_{2}$-saturated systems," in CORROSION, vol. 68, no. 2, February 2012.
[38] A. A. Sami and A. A. Mohammed, "Study synergy effect on erosion-corrosion in oil and gas pipelines," Engineering and Technology, vol. 26, no. 9, 2008.

[39] M. Baker Jr., "Stress Corrosion Cracking Study," 2004, http:// www.polyguardproducts.com/products/pipeline/TechReference/SCC_Report-Final_Report_with_Database.pdf.

[40] S. Olsen and A. Dugstad, "Corrosion under dewing conditions," in CORROSION, 1991, paper no. 472.

[41] F. Vista and K. Alam, "Semi-empirical model for prediction of top-of-the-line corrosion risk," in CORROSION, 2002, paper no. 02245 .

[42] C. Mendex, M. Singer, A. Camacho, S. Hernndez, and S. Nesic, "Effect of acetic acid pH and MEG on $\mathrm{CO}_{2}$ top of the line corrosion," in CORROSION, 2005, paper no. 05278.

[43] D. Storey, "A Service Company's Experience with Pipeline Integrity Management," 2004, http://www.roseninspection .net/MA/papers/2004-11_PipelineIntegrityManagement.pdf.

[44] P. O. Gartland and J. Roy, "Application of internal corrosion modelling in risk assessment of pipeline," in CORROSION, 2003, paper no. 03179.

[45] Det Norske Veritas (DNV RPG 101), Recommended Practice DNV-RP-101: Corroded Pipelines, 2010.

[46] Det Norske Veritas (DNV RPG 101), "Risk Based Inspection of Topsides Static Mechanical Equipment, 2001".

[47] P. K. John and L. D. John, "Risk factor analysis—a new qualitative risk management tool," in Proceedings of the Project Management Institute Annual Seminar \& Symposium, September 2000.

[48] E. J. Carl, A. B. John, and G. T. Neil, "Improving plant reliability through corrosion monitoring," in Proceedings of the Process Plant Reliability, Houston, Tex, USA, November 1995. 

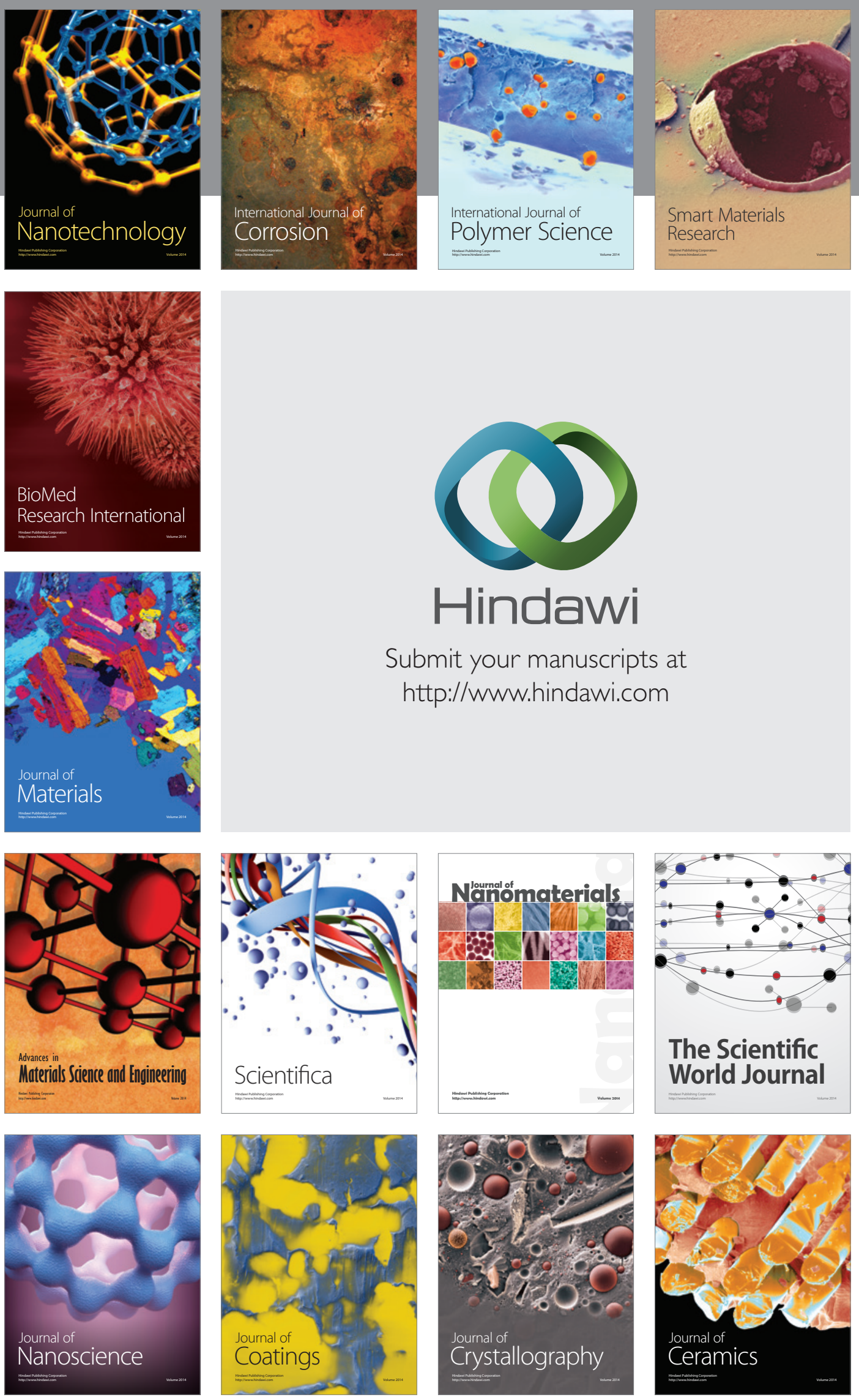

The Scientific World Journal

Submit your manuscripts at

http://www.hindawi.com

\section{World Journal}

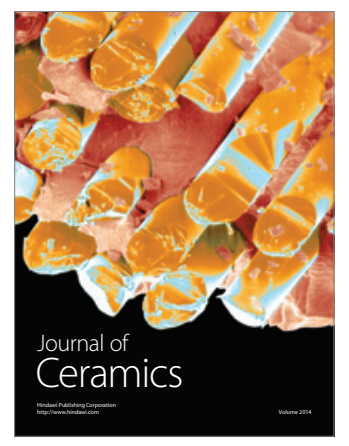

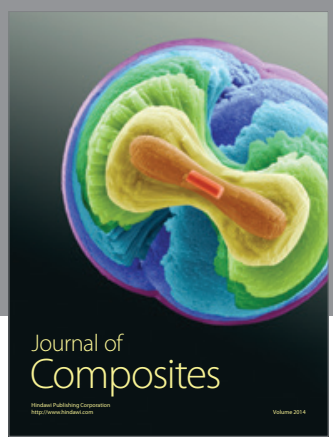
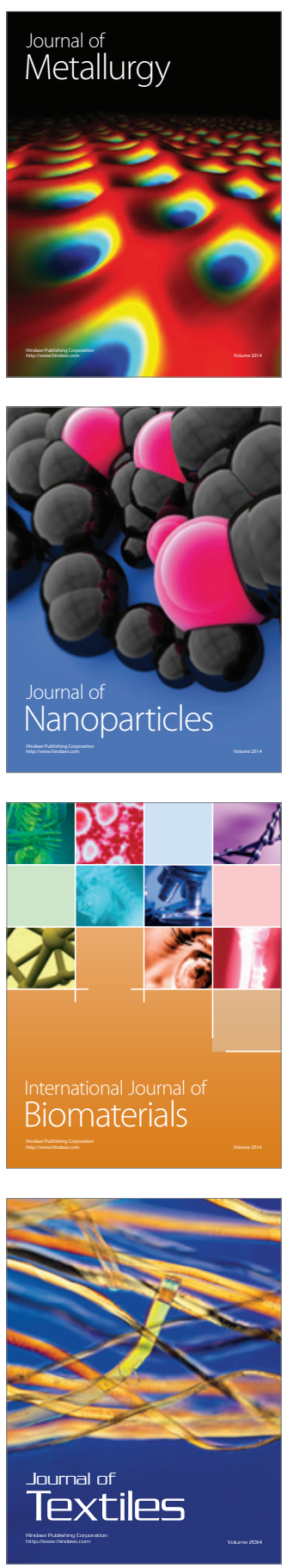